\title{
THE MAKING OF CRIMINAL LAW IN RUSSIA AND THE WEST: THE POLICY PROCESS, ADMINISTRATION, AND THE ROLE OF EXPERTS*
}

\section{Solomon Peter H. Jr.}

$\mathrm{PhD}$ in Political Science and Professor of Political Science, Law and Criminology, University of Toronto. Address: Centre for European, Russian and Eurasian Studies, Munk School of Global Affairs, University of Toronto, Room 324 N,

1 Devonshire Place, Toronto, Ontario M5S 3K7 Canada. E-mail: peter.solomon@utoronto.ca.

With the assistance of Noble B. ${ }^{* *}$

\begin{abstract}
In the new millennium, in Russia and the West alike, criminologists regularly complain about a diminishing role for experts in the making and administration of criminal policy in the West, because of pandering to the public (penal populism), and in Russia, a failure to take a systematic approach to crime control. In both places, this paper argues, these appraisals are based on idealized and unrealistic images of the way criminal law developed in the past. In North America, criminal policy-making has never conformed to a rational model as favored by some specialists in public administration. In Russia, the European ideal of a major role for criminal law scholars has been confined to periods of codification and has not served as the norm most of the time. In both parts of the world, it is essential that scholars study how criminal policy develops, in order to understand the current situation and find ways to contribute to its making.
\end{abstract}

Keywords: policy-making in criminal justice; criminal policy; criminal law scholars; normative standard for the reform of criminal law.

$\mathrm{I}^{\mathrm{n}}$ n a powerful essay published in 2004, the senior criminal law professor $\mathrm{Ni}$ nel Fedorovna Kuznetsova leveled sharp criticism at the process of adopting the 2003 reforms of the Criminal Code of the Russian Federation, many of which she saw as mistaken. The changes became law in part, she claimed, because of the failure of law-makers to consult or listen to experts in criminal law, especially the senior ones who shared her views (Kuznetsova, 2004). The adoption of changes

\footnotetext{
* A longer, Russian-language version of this article was published as a preprint in the following sources: "Sozdanie ugolovnogo prava v Rossii i na Zapade: protsess razrabotki politiki i rol ekspertov" (The Creation of Criminal Law in Russia and the West: Policy-making and the Role of Experts), in Prestupnost, ugolovnaia politika, Ugolovnyi zakon. Sbornik nauchnykh trudov, edited by N.A. Lopashenko (Saratov: Izd. FGBOU VPO Saratovskaia gos. iurid. akad., 2013), pp. 108-138. Available at: http://crimpravo.ru/blog/u_zakon/page2/

** Noble Ben - DPhil Candidate in Politics and Herbert Nicholas Junior Research Fellow in Politics at New College, Oxford. Address: New College, Holywell Street, Oxford OX1 3BN, UK. E-mail: benjamin.noble@ politics.ox.ac.uk
} 
in crime and punishment without the blessing of law scholars or criminologists would happen repeatedly in Russia during the new millennium and led a number of Kuznetsova's colleagues to express similar frustration (Boiko, Golik, Eliseev, Inogamova-Khegi, Komissarov, Koniakhin, Korobeev, Lopashenko \& Ikushin, 2010; Kashepov, 2010; Luneev, 2011; Klepitsky, 2012). ${ }^{1}$ Ironically, some of their counterparts in Western countries were also concerned that criminal policy in their countries had moved away from what they and their research supported (Loader, 2006; Loader \& Sparks, 2011). However, the dynamics of these stories differed in important ways.

For the Russian scholars in particular, the normative standard for the reform of criminal law did not correspond to the realities of political life, either in postSoviet Russia or in the USSR of Soviet times. In the view of the scholars, properly made criminal policy reflected a rational process, where logic and legal principles loomed large and experts ensured the consistency of legal changes with both. This image was close to the optimal model found in public policy textbooks in North America, with the European twist of an explicit role for legal scholars, whose contributions were treated in the civil law tradition as a source of law. For many Western scholars as well, the preferred approach to criminal policy-making included a rational process, whereby the costs and benefits of alternative approaches were assessed and criminologists (or criminology) supplied relevant empirical evidence. ${ }^{2}$ In neither place, however, did the realities of policy-making and development usually correspond to the normative ideals.

More than thirty years ago I argued that to understand, appreciate, and facilitate the role of experts in criminal policy-making in Western countries required a dose of realism about how decisions were made and what factors mattered (Solomon, Jr., 1981). A full and nuanced understanding of the policy-making process - its phases, actors, degrees of publicity - and of the actual contributions of experts over the years could provide a context for examining and assessing the contribution of criminologists. Now I suggest that the same argument applies to criminal policy in Russia.

Over the years other scholars helped enrich the portrait of policy-making in criminal justice in North America and Europe, but it was the shift of criminal and penal policy in some countries in a repressive direction not favored by criminologists that gave criminal policy-making new cachet (Miller, 1973; Stolz, 1985; Rock, 1995; Stolz, 2002; Ismaili, 2006; Marion \& Oliver, 2012, especially parts one and four). Above all, the emergence of crime as an electoral issue and the resulting politics of "law and order," even "penal populism," came to shoulder blame for the substance and direction of policy. Moreover, observers struggled to explain why penal populism itself emerged, attributing it to cultural, structural, and political factors. In the process, some of them expressed nostalgia for a different, better time in the past, when criminologists seemed to have a greater voice (Roberts, et al., 2003; Pratt, 2007; Beckett, 1997; Lord Windlesham, 1998. For a thoughtful and critical review of the literature see: Tonry, 2007; Lacey, 2012).

These sentiments echoed those of Kuznetsova and her Russian colleagues who were also disillusioned with the direction and making of criminal policy in Russia (in this case its haphazard and liberal tendencies). Whereas in the United Kingdom (UK) and the United States of America (USA), such critical sentiments led to increased attention to the policy process, this did not happen in the Russian 
Federation (RF). ${ }^{3}$ To be sure, fine scholars continued the tradition of analyzing the content of policy with the help of statistical data, but they did not study the policy process in a systematic way (See for example: Gavrilov, 2008; Lopashenko, 2009. For insightful accounts of the development of criminal policy in post-Soviet Russia see Kashepov, 2004). However, there was one criminal law scholar in Russia who started to promote such study.

In 2010 the late Alfred Zhalinsky called for the pursuit of what he called ugolovnaia politologiia, or the political science of crime. In his view this new field should be a broad undertaking that included non-governmental activities as part of criminal policy and that drew on insights from political science and economics. Researchers would address such questions as by whom and under whose influence are criminal prohibitions (zaprety) determined? On what basis are political decisions taken? What political processes and competition for influence are involved? Why in Russia do convictions for criminal offenses lead to more severe consequences than in other countries without gains in effectiveness? (Zhalinsky, 2010; Zhalinsky, 2010 a). Sadly, this innovative elder statesman of criminal law scholarship died before pursuing this kind of research and thus far no one has taken up his challenge. Hopefully, this essay will reinforce Professor Zhalinsky's message.

My purpose here is to describe Western approaches to criminal policy-making, including the role played by experts (criminologists and criminal law scholars), and to suggest how research and analysis could shed light on the situation in post-Soviet Russia. It begins with examination of key components of the policy process (phases, actors); distinctions among types of politics and political issues (low key versus public; symbolic versus instrumental); and refinements in the analysis of process (policy windows, issue attention cycles). It then turns to the traditional role of experts in Common Law countries and then in the age of penal populism, asking to what extent the underlying problems have changed. The discussion then turns to the patterns of policy-making found on the continent of Europe in recent decades. Finally, the paper provides an overview of the way that criminal policy has been made in the USSR and in post-Soviet Russia and thoughts about how deeper study of the process might enhance understanding the role of criminal law scholars in Russia today.

\section{The policy process in criminal justice and its study}

In Russia, scholars often treat changes in the criminal law (Criminal Code) as a technical legal matter, downplaying their political dimension. But the criminal law is also one of the central components of criminal policy, the government's approach to the definition and management of crime. In modern states, choices relating to criminal policy and law often involve considerations other than legal concerns. Moreover, a range of actors may participate directly or indirectly in the promotion of ideas and making of decisions - about the content of the law, the procedures and institutions used to enforce it, and choices their leaders make about implementation.

The study of criminal policy-making in the West has used concepts and approaches developed for the study of the development of policy in any realm. More 
than thirty years ago the author of this essay showed how the division of policy-making into three or four stages could provide a good starting point for further analysis (Solomon, Jr., 1981). The stages he identified were: agenda-setting, decision-making, implementation, and evaluation. Let us discuss these stages in reverse order. The evaluation of policies after their adoption and supposed implementation did not always happen, but it still represented a possible and desirable end point, and worth examining when it did occur. The implementation of policy choices including those expressed in legislation represented a crucial part of the study of policy-making, because implementation of many laws was in practice far from automatic and could have unanticipated consequences, including distortions of the policies themselves.

The decision-making phase referred to activities starting from the moment that a proposal was taken seriously by an executive agency or parliamentary committee (that is, placed on the political agenda) to the ultimate decision by those empowered to pass laws. This might feature discussion of alternative approaches in public at committees or in private in the exchange of memoranda by bureaucratic agencies and interest groups. And such interplay of political forces might prove decisive in the determination of the outcome, as anticipated in the classical pluralist model of politics. However, to many analysts the politics surrounding particular decisions did not capture the whole story, especially of the exercise of power, for the decision-making process revolved around only those issues and alternatives that had reached the political agenda. There might be other issues or more radical approaches that were not being considered.

This concern led to the identification and broad acceptance of the idea of another phase of the policy process prior to decision-making, what analysts call "agenda-setting." This abstract term refers not to the formation of the agenda of a particular institution like a parliament, but to the pool of ideas and approaches that relevant actors treat as potentially acceptable and worthy of consideration. Agenda-setting itself is a diffuse process characterized by social learning (by policy professionals, elites, the public), as problems become sufficiently acute as to demand new solutions. While the screening out of unacceptable ideas is an ongoing repetitive process that applies to any potential policy choice, the embracing of new approaches matters especially for innovations, whose acceptance onto the political agenda often follows a crisis (On agenda-setting, see: Kingdom, 1995; Jones \& Baumgartner, 2005; Baumgartner, et al., 2006). Examples of innovations in criminal policy might include the adoption of imprisonment as the modal form of punishment (early nineteenth century); the invention of parole, probation, and juvenile justice (late nineteenth century); prohibition of production and sale of alcoholic beverages (United States and Russia, early twentieth century); the criminalization of narcotics trade and use (early twentieth century); the decriminalization of homosexual relations and of adultery (late twentieth century) ; and the criminalization of the investment of illegally obtained funds (money laundering) as an approach to transnational and organized crime (late twentieth century) (Studies of these developments include the following: Rothman, 1971; Rothman, 1980; Gusfield, 1963; Schrad, 2010).

The actors involved in criminal policy-making fall into three groups: politicians (in the executive and legislative branches); professionals (officials in minis- 
tries; line authorities like police chiefs, chairs of courts, heads of prisons; ordinary practitioners such as police, judges, prosecutors, defense counsel, social workers, and probation officers; and officials involved in planning and research, especially within ministries and commissions, as well as external experts); and the public (interest groups, public opinion and the media that shape it).

In most Western countries the involvement of politicians was traditionally episodic and involved taking advice from officials and experts regarding new legislation to address urgent matters. To be sure, issues that attracted public interest, like capital punishment, gun control, or parole, commanded the attention of political leaders, who were concerned about public mood and its potential impact on elections. But only in recent decades, and especially in Anglo-American democracies, have rival political parties vied for public approval in the protection of law and order, a syndrome that has resulted in more severe punishments and frequent changes in the criminal law. We will examine such "penal populism" later on.

Professionals in criminal justice, as we have seen, comprise different kinds of officials, whose views on issues probably diverge more often than they agree. Operational officials determine to a large extent how legislation gets realized, through both directives and patterns of action. In addition, their views, along with those of policy and research staff of the agencies, often shape legislative initiatives, especially when they are not politically visible or controversial. At times, such constituencies may exercise a veto power. Further, many of the same officials (judges, police chiefs) may be represented by professional organizations that act as interest groups.

Finally, the public itself may exert influence on criminal legislation and other policy choices. Democracies often feature interest groups designed to promote particular ideas (abolition of the death penalty, legalization of abortion, restrictions on ownership of hand guns, penal reform) or to represent particular groups (the victims of crime). Further, readings of public opinion or mood by pollsters, itself shaped by media accounts of particular incidents, are used by politicians to support initiatives. Too often the resulting "public opinion" represents emotional reactions to questions by uninformed respondents rather than judgements of persons informed about the issues.

One of the key factors in the policy process that shapes outcomes in criminal policy is the degree of public attention an issue arouses. In the abstract one can imagine a spectrum of possibilities ranging from decisions taken wholly outside the glare of the media, to issues that have a public dimension, to matters that actually become subjects of partisan politics. Once there is any public dimension connected to a potential change in the criminal law or justice, another factor may enter the equation, namely its symbolic meaning. Adding an offense to the criminal law may satisfy the demands from part of the public or interest groups by supporting its values - apart from any potential enforcement.

The symbolic dimension also looms large in the politics of punishment, especially the matter of abolishing capital punishment. In no country where this step has been taken did public opinion approve it in advance, and in countries (and states within the USA) that retain the ultimate sanction its actual use is subject to fluctuations that may include long periods of inactivity. In these situations 
the symbolic value of keeping the penalty in reserve has outweighed the outright rejection of retribution and the value placed on human life (Zimring \& Haskins, 1986; Hood \& Hoyle, 2009).

Studies of public policy in the West also suggest patterns of policy development that reoccur. One pattern revolves around cycles of attention, positing that politicians do not usually focus on the same policy areas or issues for long, dealing with them only for short periods of time and then ignoring them until a problem arises. Another related idea is that of policy windows, that is, opportunities for the pursuit of particular approaches to a problem (Marion \& Oliver, 2012. Ch. 4). The decriminalization of marijuana possession in eleven states of the USA in the 1970s (and the consideration of this possibility in other states) became possible because of a unique confluence of circumstances. This option got onto the agenda of policy-making when it became clear that prosecutions were often directed against middle-class youth for whose future careers the stigma of a criminal conviction could cause problems. At the same time, law-enforcement officials (police and prosecutors) often supported decriminalization as a way to reduce caseload. However, the policy window produced by this confluence of circumstances lasted only a few years and then closed. By 1980 a conservative mood had emerged in the USA, and the symbolic value of keeping marijuana use a crime became the dominant view. No further states chose to decriminalize, and one state decided by popular referendum to recriminalize (Alaska in 1990) (DiChiara and Galliher, 1994). In fall 2012 the states of Colorado and Washington decriminalized marijuana use by popular referendum, suggesting that a new window of opportunity had opened.

\section{The role of experts: before the era of penal populism}

By the 1960s, in both the USA and the UK, criminology was a fast-growing field of scholarship and recognized by government officials as a source of expert knowledge. In both countries criminologists were drawn into the worlds of policy-making, in the USA to help react to outbreaks of violent protest and in the UK to contribute to routine improvements in the administration of criminal justice. On both sides of the ocean, however, the experience left a bitter taste in the mouths of scholars, who felt betrayed when their voices did not hold sway or, worse, their findings were used to support choices with which they disagreed (Komarovsky, 1975; Hood, 1974). To this writer the laments of the experts reflected confusion about the nature of the political process and ways that ideas of any kind leave their mark.

It is helpful to picture social scientists as performing two main functions in policy-making: solving policy problems and providing new perspectives on policy for all concerned. The problem-solving function would bring social scientists into decision-making; the "enlightenment function" would bring them into the agenda-setting phase. Moreover, the political process was not a rational process of weighing of substantive alternatives, but involved other mechanisms of choice, such as voting, bargaining, and compromise. In this context, all knowledge, including that coming from research, served as an instrument for the players rather than a source of direction 
The normal and most typical pattern of criminologists' contributions to policy that obtained in Anglo American democracies from the 1960s to the mid1980s consisted of a long-term process that is not easily traceable, which involved a number of studies and writings whose cumulative effect might lead to new visions and approaches.

\section{Penal populism and its impact on the role of experts}

In the Anglo-American world, especially the USA and the UK, the late 1980s, 1990s, and beyond observed a shift in penal policy in the direction of severity. To many observers, the new severity was correlated if not intimately connected with the politicization of crime and punishment, as competing political parties and candidates sought to demonstrate their toughness in confronting criminals. As policies on crime and punishment reflected appeals to the public more than efforts to achieve results, observers identified a new syndrome that they called "penal populism" or "populist punitiveness" (Bottoms, 1995; Pratt, 2007).

To be sure, the dramatic rise in rates of imprisonment in the UK and extraordinary expansion of prison populations in the USA had other root causes, including the decline of the rehabilitative ideal even among liberals and a concern for equity (a factor in producing determinate sentencing and increased prosecutorial powers). There was a tendency for scholars of a liberal persuasion to blame the new severity on what they saw as a distorted policy-making process. The increased concern of politicians with appealing to public opinion (assumed to be harsh) implied less attention to evidence and expertise, so that the role of public servants (bureaucrats) and experts (criminologists) declined. In the new millennium some of the latter voiced their dissatisfaction and debated ways that criminology could regain its former public role (Loader, 2001; Lacey, 2008).

The simplified portrait of a shift from policy-making that took some account of evidence and expertise to one driven mainly by ideology and political competition works best for England, where the law on crime and punishment is made in one place (not 51, as in the USA) and criminologists were in physical proximity to the centers of power. Ian Loader constructed a portrait of England in the 1960s and 1970s as a world of criminal policy dominated by a network of officials and experts, something close to a "policy community." These "Platonic guardians" assured that radical breaks with the past were discouraged and that evidence was at least considered, though not always determinative (consider the Criminal Justice Act of 1972). While the Conservative party won the parliamentary elections of 1979 with a law-and-order platform, for more than a decade its leaders pursued moderate penal policies, even discouraging imprisonment, in large part due to the actions of key civil servants (Rutherford, 1996, pp. 85-117; Downes \& Morgan, 2007). This romantic portrait of a golden age of criminal policy-making gains credibility mainly in comparison with what followed after 1993, a period when a series of Home Office secretaries of different political persuasions aggressively moved penal policy in the direction of severity. This happened when crime rates had begun to fall and well after the decade of conservative domination in politics, a period when the temptations toward severity had been checked. After that, 
it appears that the close ties between officials of the Home Office and criminologists disintegrated and the latter were rarely consulted (Newburn, 2007; Lord Windlesham, 1996; Loader, 2006).

The reality of penal policy-making in the United States was more complicated and fits the caricatured portrait only in part. Overall, punishments did become more severe during the 1980s and 1990s, but often not because of politicians' appeals to the public. On the federal level, the introduction of determinate sentencing at the end of the 1970s, with bipartisan support and expert involvement, was the most important factor, while at the state level there were multiple scenarios (See, for example, Sith \& Cabranes, 1998). To be sure, in some states politicians and elected district attorneys did engage in penal-populist appeals, but in others they did not even respond to public pressures, and there were some states where punishments did not become more severe (e.g., Washington state, where cooperation of government officials with societal actors produced a European-like restraint) (Barker, 2009).

On the federal level, the politics of law and order played a big role in the victory of William Jefferson Clinton in the 1992 presidential elections, but it did not lead to repressive policies or measures that did not meet the expectations of criminologists. The centerpiece of the eventual omnibus legislation of 1994 related not to increases in punishment but to the supply of police officers; the federal government decided to provide financial support for 100,000 new police at the local level. In so doing, it required recipient local governments to develop community policing programs, a step generally regarded as progressive.

Most European countries have so far been insulated against the effects of penal populism, real or potential, though the politics of law and order did emerge as factors in most Anglo-American countries (even in Canada later on, under the Harper Conservatives). Moreover, many criminologists in those countries believed that this development cut them off from the policy process and produced a politicized result. ${ }^{4}$ Although misguided to a degree, this alienation of criminologists represented a reality in some Western countries that could be compared with developments in the Russian Federation. It is appropriate first, however, to examine in more detail recent experience in criminal policy-making in Europe, to have another baseline for consideration of Russia.

\section{Experts, public opinion, and the criminal policy in Europe}

The European approach to criminal law and policy has been marked by two mutually reinforcing traditions - the tradition of elite domination with low levels of politicization; and the tradition of a prominent role for legal scholars. Moreover, consistent with the civil law tradition, legal scholars typically played a major role in discussions of changes in the law, especially when codes were involved, and the scholars themselves valued consistency within the law and treated its inner logic as a guiding principle (Tonry, 2004; Merryman, 2007). In the civil law tradition, codes were meant to have an organic quality and display a systematic approach to their subjects, qualities often absent in codes within the Anglo-American countries. ${ }^{5}$ In the latter, legal codes usually represented 
attempts to collect in one place prohibitions, sanctions, and principles with multiple origins, including case law.

A key question is the extent to which these traditions have been maintained in recent decades, as mass media changed and instantaneous communication became the norm. For the most part, continuity rather than change has characterized the development of criminal law and policy in most countries of Western Europe. Over all, there was neither a significant growth in penal populism or law-andorder politics nor a decline in the role of legal scholars. Nor have the practitioners of social science research on crime and justice, criminologists, joined, much less supplanted, the legal scholars, in part because criminology is typically not an autonomous enterprise but subordinate to the study and teaching of law.

In Germany the traditional pattern of criminal law reform was replicated in 1959, when after a few years of studies, the Federal Minister of Justice established a Grand Criminal Law Commission composed of politicians, legal practitioners, and legal scholars, which produced the draft criminal code of 1962. According to critics, the draft Code failed to move beyond a traditional retributive approach and pay heed to rehabilitation, so that even members of the Commission acknowledged that their product did not reflect a "modern criminal policy." The reform effort seemed doomed to fail when a private group of 14 German (and Swiss) criminal law scholars and criminologists moved into the void and produced an Alternative Draft Criminal Code (whose general part published in 1966). This "professorial initiative" then gained support from the main political parties in the legislature and shaped the actual reform of the criminal law in Germany. However, this did not involve actual adoption of the Alternative Code, but rather its actualization in a series of separate criminal law acts over the next eight years. In effect, Germany adopted what Continental jurists saw as an English model of step-bystep change or "reform by installments." By 1975 five criminal law reform bills had introduced more than seventy-five important changes in the German Criminal Code, many of which had their origins in the proposals of the "professors."

The development of the criminal law through evolutionary change (rather than grand design) has lasted in Germany as particular acts have introduced specific changes. These have included the Crime Victims Protection Act of 1986, the Fight Against Organized Crime Acts of 1992 and 1996 (introducing moneylaundering provisions), the Fight Against Crime Act of 1994 (dealing with hate crimes), the Sixth Criminal Law Reform Act of 1998, and the 1998 Law on Sexual Offenses. Although the early liberalization trends ended, there does not seem to have been a punitive turn in Germany (non-custodial sentences and short terms of imprisonment are still the norm), where criminal policy was marked above all by stability and inertia. Even in the wake of unification, there was no increase in public fear of crime, and the political parties (as of the turn of the millennium) still refrained from making crime an electoral issue (Eser, 1996; Krehl, 2003; Oberwittler \& Hofer, 2005; Tonry, 2004).

In other European countries with stable patterns of punishment, one does not find much (or any) penal populism, and the policy-making process continues to feature professionals, both officials and experts. The literature demonstrates this for France and Belgium, and it was likely also the case in most Scandinavian 
countries (Tonry, 2004). In contrast, in the Netherlands - the European country with the most dramatic expansion of imprisonment (especially of offenders from minority ethnic groups such as Moroccans and Antilleans) - both public opinion and the leaders of political parties began to see crime as a sign of social disintegration within their multi-ethnic society that called for reaction. Highprofile murders aggravated the problem, and new measures of social control like identity cards were introduced. Crime talk became alarmist and emotional and the attention given to experts declined sharply (Pakes, 2006; Downes \& van Swaaningen, 2007).

In Europe as in North America, punishment represented only one dimension of criminal policy, and in other areas there was a greater likelihood of avoiding the impact of public opinion and the politics of law and order. A case in point is policy toward criminal control of drugs. The most dramatic change in this realm came in Portugal, which in 2002 decriminalized the possession of up to a ten days' supply of not only cannabis but also hard drugs, and the movement of such possession to the realm of administrative offense. This dramatic step was based on consensus about the ineffectiveness of prosecution and convictions in reducing drug use in this country of drug trafficking and embarrassment about the resulting public health crisis. This consensus included officials in both health and criminal justice, many of whom saw drug convictions as a source of prison overcrowding. De facto decriminalization, or restrained enforcement, preceded legal decriminalization in the 1990s, and new research soon followed that highlighted the connection between the HIV virus and drug users in Portugal. The actual reform was elaborated by a government-appointed expert commission. In short, the policy-making process was inclusive and evidence-based and it led to a new paradigm. The effects of the change were dramatic. As a result, the number of persons convicted of drug charges dropped within a few years by more than 60 percent, and the share of drug convicts in prisons dropped from 44 percent in 1999 to 21 percent in 2008. Prison density fell from 120 to 101.5 per 100,000 of population (Hughes \& Stevens, 2010; Hughes, 2006, especially Ch. 4: "Drug Policy Reform in Portugal"). This snapshot of criminal policy-making in countries of Western Europe in recent decades (based on material in English) shows that the pressures of law-and-order electoral politics did not change the policy-making process in most countries or for most issues. More often than not, the traditional model, where officials and legal experts joined politicians in shaping policy, remained in place. This contrasted with the changes that took place in England and at least some of the states of the USA, and suggests multiple baselines against which to assess Russian developments. At the same time, one should not exaggerate the role of criminal law scholars (not to speak of criminologists). While they were often participants in discussions of possible change, helping to form the agenda of reform as well as contributing to choices, their voices were rarely dominant and innovations in criminal policy required the support of other professional constituencies with different values (as shown in the Portuguese case of decriminalization of personal drug use). But criminal policy did not stray to extremes - of severity or of instability - and the experts did not experience intensified alienation. 


\section{Criminal policy-making in the USSR}

Over the course of Soviet history, all major efforts to shape and reshape the criminal law (and criminal procedure as well) through revision or rewriting of the Criminal (and Criminal Procedure) Codes followed European practice and involved legal scholars. But there was never a time when the leader(s) did not also use their prerogative to make changes in crimes and punishments on their own, with little if any consultation. The two modes of decision-making coexisted under Iosif Stalin, Nikita Khrushchev, and Leonid Brezhnev, although their balance and meaning changed more than once.

Not long after the promulgation of the Stalin Constitution at the end of 1936 and until the last year of Stalin's life, legal officials and scholars were engaged off and on in the preparation of a USSR Criminal Code, with drafts produced in 1938-39, 1946, and 1949. The drafting process in the late 1930s was the most visible, and one can learn from the journals about the drafting activity of the scholars (multiple commissions), the content of proposed changes, and later discussions among legal experts. The draft Code included a number of reforms, including the abolition of the principle of analogy, a change with large symbolic meaning that was supported by the leading authority in the law, Andrei Vyshinskii. The postwar period witnessed the resumption of work on the Code (required, now that criminal law was in all-Union jurisdiction), with Moscow-based scholars (especially from the All-Union Institute of Juridical Sciences) included in a new Commission and its two subcommissions, one for the criminal and one for the criminal procedure code, which met 92 times in 1946 and 1947. There followed broad behindthe-scenes consultations (including comments from at least three Central Committee secretaries, and in 1949, the Supreme Soviet's Committee on legislative suggestions established a subcommittee for further review. Along with removing analogy, this draft Code was set to revive parole (abolished in 1939), to raise the age of criminal responsibility from 12 to 14 , and to narrow the definition of shirking (progul). In contrast to the prewar period, this time, work on the draft criminal code stayed entirely behind the scenes and was barely mentioned in public. ${ }^{6}$

These same years witnessed many important changes in the criminal law that came directly from Stalin himself, including the criminalization of labor discipline breaches (1940), the elimination of the death penalty (1947), new penalties for rape (1949), and draconian laws on theft (1947). While in these and other decisions, Stalin sometimes consulted his top officials, such as the Chairman of the Supreme Court or the Minister of Justice, often he did not heed their advice, let alone involve legal scholars (Solomon Jr., 1998 and 2008, Ch. 12).

In the first years after Stalin's death, the same dualistic approach to criminal policy continued unchanged. Between 1953 and 1955, corrections to the severity and scope of the criminal law were made through individual edicts, while at the same time the drafting of a USSR Criminal Code was revived and put in the hands of a commission of officials and scholars from Moscow. Khrushchev opened the way for more active and broader participation of legal scholars in the preparation of All-Union Fundamental Principles of Criminal Legislation and republican criminal codes (now required by Khrushchev's return of jurisdiction for criminal 
law to the union republics). The drafting of the Fundamental Principles featured a large commission that included scholars from outside Moscow and a significant degree of specialization, and at least the discussion of its work entered the public sphere, culminating with public discussion of the draft principles in 1958 that was dominated by jurists. Lively discussions included such contentious issues as the design of a revived parole and the provisions for dangerous recidivists. Similar discussions were organized for the draft Fundamental Principles of Criminal Procedure, where divisions within the legal community among liberals and conservative jurists were more pronounced than on matters of criminal law. The ultimate decisions on matters of controversy remained in the hands of political leaders (secretaries of the Central Committee of the Party), although they were sometimes delegated to the top legal officials. But both sets of Fundamental Principles included changes not in dispute that had been on the agenda for years, in part because of the voices of scholars (e.g., the elimination of analogy) (Solomon Jr., 1978, Ch. 3; Gorgone, 1976; McCain,1982).

By 1961, the period of codification was over, and jurists expected that Khrushchev would observe the promise that law reform remain in the hands of the legal community and its specialists. But Khrushchev was quick to disappoint, and in a few years became notorious for introducing on his own severe punishments for economic crimes (with prosecutions directed especially against Jewish businessmen), even including retroactive use of the death penalty. He also expanded the crime of "parasitism" and entrusted lay bodies (comrades' courts) with the imposition of real punishments, to the dismay of specialists in criminal procedure (Berman, 1963, Ch. 2; Feofanov, 1989. For more on criminal policy under Khrushchev see: La Pierre, 2012). In sum, his actions reinforced the view among legal scholars that politics was an unwelcome intruder on their terrain.

In contrast, the early years of the Brezhnev-Kosygin partnership produced a new basis for expert involvement in criminal policy-making. The revival of criminology (empirical social research on crime and criminal justice) from the late 1950s gained institutional form with its prominent place in the recast Procuracy Institute (from 1963 known as the All-Union Institute for the Study of the Causes of Crime and Development of Measures for its Prevention). With the Brezhnev leadership's commitment to scientific management of society, there was ideological support for evidence-based policies. Accordingly, in the second half of the 1960s, criminal law scholars armed with criminological expertise played a prominent part in decisions on such matters as approaches to juvenile offenders, alcohol and crime, parole and recidivism. Scholars provided important material in defense of parole when the institution came under attack, and helped refine the criteria for designation as an especially dangerous recidivist. Perhaps more important, criminologists as a group helped to make crime prevention a priority within Soviet criminal policy for at least a decade (Solomon Jr., 1978, Ch. 4 to 9).

The latter years of Brezhnev's rule and those of his immediate successors (to 1985) represented a period of relative continuity in criminal policy, as the leaders showed little interest in initiating major changes. They presided over a series of small changes in the law that came in response to the needs of law enforcement and did not usually involve expert input. Whether such changes were exces- 
sive in number or justified in practice requires special study. Simple counting of the number of changes in the Code (by article) yields the following. Between the 1964 leadership change and 1980, there were close to six individual changes in the Criminal Code per year; in the 1980s nearly thirty changes per year; and between 1990 and 1995 (before the new Criminal Code of the RF was adopted), over fifty changes per year. ${ }^{7}$

Many of the changes in the Brezhnev era had the effect of enlarging the scope of the criminal law and increasing the severity of punishment. Of course, these changes were accompanied by the usual flow of regulations about law-enforcement practice, including guiding directives of the supreme courts on how the criminal law should be applied and interpreted. These should be taken into account in any serious account of the durability of a Code's meaning and application. Thus, the drop in the share of custodial sentences of 11 percent between 1983 and 1985 and of another third between 1985 and 1987 reflected policy changes manifested in regulations far more than changes in the law (Solomon, Jr., 1992).

For criminal law scholars, the decade and a half before 1985 was to a large extent a time of waiting. It was a time for the accumulation of ideas about change, prompted in part by defects in the administration of justice and in part by increasing awareness of and references to reforms undertaken in socialist countries of Eastern Europe. In the first half of the 1980s, a group of criminal law scholars began working on model legislation, including Model Fundamental Principles of Criminal Legislation that were completed in 1985 and published in 1987, and a Model Criminal Code for the RSFSR completed in 1986 and not published. In the course of this work, many criminal law scholars became prepared for reconsideration of the content of the criminal law and, armed with their own agendas, including the need to reduce both the scope of the law and the severity of punishment (Naumov, 2012; Kudriavtsev \& Kelina, 1987).

The new policy of glasnost announced by Mikhail S. Gorbachev in 1986 opened the door to serious public discussion of abuses in the administration of criminal justice and the mounting of pressure for reform, especially in criminal procedure, courts, and law enforcement. Legal scholars played major parts in both of these enterprises. At the same time, the political leadership and top legal officials recognized the need for reform of the criminal law as well, and already in January 1987 a Party plenum established drafting commissions for both Fundamental Principles and a new RSFSR criminal code, Heavily influenced by the model principles, the new draft fundamental principles were published in December 1988, received public discussion in 1989, and were submitted to the Supreme Soviet in 1990 and adopted in summer 1991. A number of the authors of the Model principles helped draft the ones that were adopted (Solomon, Jr., 1992).

The Fundamental Principles of Criminal Legislation adopted on the eve of the breakup of the USSR represented a fresh approach to punishment and crime, reflecting the best of scholarly thinking. Highlights included an emphasis on noncustodial sanctions and a series of principles that limited criminal responsibility (actual decriminalization could be effected only in the special parts of criminal codes). Among the principles designed to limit criminal responsibility was the idea that the taking of professional and economic risks that might involve breach- 
es of the criminal law by managers or businesspeople could be justified. This step represented the start of a series of concrete measures aimed at legalizing and facilitating private business in Russia. When the USSR disappeared as a state, the Fundamental Principles lost their legal status, but they remained as a source for the persons working on the new criminal code of the Russian Federation, which succeed the RSFSR.

\section{Criminal policy-making in the Russian Federation: the 1996 Criminal} Code and the Law of 8 December 2003

The decade spanning the last years of the USSR and the first years of the Russian Federation (1985-1995) - a tumultuous period in Russian history - was a time of major change in the criminal law, effected both through codification with normal expert participation and countless direct changes in the criminal law. As a rule, the latter came as initiatives of officials and politicians, were supervised by the relevant department in the administration of the President, and did not involve expertise. But many of those changes were justified by the demands of the hour, including desire to reduce the severity of Soviet law (e.g., by narrowing use of the death penalty and the opposing need to respond to the crime scare generated by the media from 1989). During these years, scholars expressed little resentment about the way changes were adopted, perhaps because of their involvement in the ongoing preparation of a new criminal code for the Russian Federation that would allow them to reconsider those changes in the old code.

The perspective of criminal law scholars in the RF would change in the fifteen years after adoption of the Criminal Code of 1996, as a constant flow of amendments kept changing the law that had been carefully fixed and criminal law scholars recognized that their influence had waned. Some were aware that, in the past, their participation and direct influence had been limited to periods when new codes were the order of the day, but that concrete changes were often introduced without broad consultation. But there seemed to be two novelties in the post-1996 period: first, the sheer volume and frequency of such changes (despite the fact that a new Code had just been promulgated); and second, the apparently low level of participation and influence of experts in two major initiatives - the large package of amendments to the Criminal Code of December 2003 and the changes introduced in two omnibus laws in 2011 to realize the Medvedev program of humanizing the criminal law.

Were the scholarly critics right? Had they been excluded more than in the past? If this was so, how could one explain this trend? These are questions that deserve attention. Another related one is the extent to which the policy-making process in the criminal realm changed in post-Soviet Russia. In particular, what difference did a more active legislature make? Did Duma deputies play an inappropriate, even harmful role that responsible members of the executive branch (especially in the presidential administration) could or did not combat? To what extent were appeals to the public of a populist variety a relevant factor? On the basis of existing knowledge, which is only fragmentary, we try to develop tentative answers that can stand as hypotheses for future inquiries. We will start with 
the making of the 1996 Code, and then turn to its first fifteen tumultuous years, including the packages of changes introduced in 2003 and 2011.

The drafting of the 1996 Criminal Code was a complex and extended process. It began with the production in 1991-92 of two competing versions, one produced by the Ministry of Justice, the other by the RSFSR Supreme Soviet, both of which included most of the new Fundamental Principles in its general part. Each also involved scholars in its drafting groups. The Justice draft was further revised at the administration of the President, and later a group of deputies produced a new coordinated draft based on the two latest versions of the competing versions. During 1995 this combined version was circulated for comments according to the usual procedures (that is, to interested governmental agencies and to regional governments), approved by the Duma, rejected by the Federation Council and overridden by the Duma, vetoed by the President (in part because the Federation Council's objections had not been accommodated), revised by the Duma, again rejected by the President because of failure to coordinate with criminal procedure law, revised by the Duma once again, and finally approved by all concerned (Naumov, 1997; Butler \& Henderson, 1998; Pomorski, 1998). After the many years of preparation, the last stages of the process moved quickly, resulting in the usual complaints about haste. Much of this activity took place in the public glare, and periodicals like Iuridicheskii vestnik, Chelovek i zakon, and Rossiiskaia gazeta published detailed discussions of the content of the various drafts.

In its final version, the new Code did not break dramatically from the Soviet past (besides enshrining obvious changes, such as the end of speculation as a crime, and tidying up the General Part of the Code). The new Code actually added more crimes than it removed, including a package of new business crimes that would soon become controversial (chapter 22), in part because of the treatment of business leaders as members of organized groups. The levels of punishment, while adjusted to the new classification of crimes, remained harsh by European standards, although provision was made on paper for a number of new non-custodial alternatives. However, these required organization and investment before they could make their mark, so that a conditional sentence became in practice the main alternative to imprisonment (Ibid.; Ugolovnyi Kodeks Rossiiskoi Federatsii: Ofitsialnyi tekst, 1996).

Between mid-1998 and 2002, twenty-five separate laws introduced changes into the Criminal Code of the RF, for the most part adding new criminal offenses. Moreover, there were also many legislative proposals sponsored by individual deputies in the Duma, most of which were screened out by a council of experts working with the relevant committee in the Duma that included scholars. The overall situation was sufficiently chaotic that the upper house of the legislature, the Federation Council, decided to take the initiative and organize hearings - "The Criminal Code of the RF after Five Years: Problems and Perspectives on Improvement" - where scholars played an important part. The hearings produced a substantial list of recommendations approved by the parent body on 23 April 2002 (Kuznetsova, 2004).

Less than a year later a draft law was submitted to the Duma by the President in March 2003 under the banner of "humanizing the criminal law," which led in turn to the omnibus law of 8 December 2003. While the original bill involved fifty 
changes, the actual law ended up affecting two-thirds of the articles in the Code, among other things introducing greater possibilities for non-custodial alternatives including fines and a better deal for juveniles. It also removed confiscation of property as a supplementary punishment (replacing it with large fines that seemed easier to collect), made trafficking in persons a crime (fulfilling international obligations), and decriminalized such common offenses as cheating customers, possession of hand weapons, most forms of ordinary hooliganism (now a weapon was required), lesser drug offenses, and accidental imposition of moderate degrees of bodily harm. There were also changes in the general part of the Code (often problematic for scholars), including the elimination of repeat offenses as an aggravating factor and a new approach to punishment for multiple charges, which while practical did not meet standards of logic. The law also included peculiar borrowings from other areas of law, such as the provision that parents could be held responsible for paying fines imposed on juveniles! (Kondrateva, 2003).

From the critical comments of scholars one might assume that the package of measures included in the December law was an arbitrary hodgepodge that had not been thought through, but this was far from the case. The idea for the law came about in spring 2002 (the same time as the Federation Council hearings), when the President concluded that the prison population of the Russian Federation was too high but disliked large-scale amnesties as a means to rectify this. Better, he thought, to make the system of punishment more differentiated, so that lesser offenders and young offenders did not end up in confinement. From August 2002 through February 2003 a high-level working group chaired by Deputy Head of the Presidential Administration Dmitrii Kozak (who had run similar groups dealing with judicial reform and the federal system) met at the Kremlin to study data on the effectiveness of punishments and sentencing and debate exactly which changes should be included in the new law. The group included representatives of all the law-enforcement agencies (MVD, FSB, Miniust), the Supreme and Constitutional Courts, the chambers of parliament (Aleksandr Barannnikov), and perhaps rights groups (Lev Levinson). According to a retired procurator general (who had once served as head of the Procuracy Institute), there were no representatives of "scholarship," in particular from the Institutes of the Procuracy and the MVD. But it is evident from articles presenting the draft law in the press (and the Explanatory Memo that accompanied it in the Duma) that its contents had received careful consideration of evidence and the pros and cons of alternative approaches, including those suggested by the Federation Council on the basis of presentations by scholars. Other items considered may also have reflected scholarly input (Sukhov, 2003; Chernov, 2003; Ozerova \& Shipitsyna, 2003; Gromov, 2003; Rubtsova, 2003; Svetova, 2003). ${ }^{8}$

There was no sign of posturing for public consumption, especially along the lines of penal populism. For the most part, criminal law scholars critical of the bill objected to its leniency vis-a-vis repeat offenders, as well as a few concrete measures to which they would have objected earlier had they been members of the working group (See, for example, Boiko, et al., 2010).

Sadly, the law did not produce many of the desired effects. To be sure, the overall prison population of the RF went down temporarily, between 2003 and 2005 from around 788,000 to 630,000, but within a few more years it had returned 
to the original level, in part because of changes that reversed measures from 2003 (including reversals in the handling of drug charges and an expansion in the lower level for theft set in 2002). The percentage of convicts sentenced to imprisonment went up slightly in this period, but this may have reflected the substantial decriminalization of offenses like hooliganism. ${ }^{9}$ By the time Dmitrii Medvedev was selected to succeed Vladimir Putin as president, the challenge once again was to reduce the prison population and the method adopted was a new program of "humanizing the criminal law."

\section{Criminal policy development under President Medvedev}

Early in his presidency, Medvedev announced that Russia's system of crime and punishment had become too severe and too costly, and he called for its humanization. Within a year he also recognized the special problems posed by the overuse of the criminal law in the regulation of business in the RF, by providing patronage to an active and concerned group of jurists and economists who had addressed it, in effect putting this matter as well onto the policy agenda. These steps would lead to three pieces of legislation, one restricting pretrial detention for businessmen (spring 2010) and two (March and December 2011) that again changed the scheme of punishments in the Criminal Code and introduced further decriminalization (for example of slander). For these initiatives, the most important policy-making center was the presidential administration, where Mikhail Paleev from the State Legal Administration directed the key working groups. Despite indirect contributions, many criminal law scholars believed that both they and their science had not been sufficiently involved..$^{10}$

An important source of ideas contained in the Medvedev humanization program was a retired deputy chief judge from Supreme Court then working as a scholar at a research institute. During 2007-08 Vladimir Radchenko recognized the counterproductive situation in Russia of an exceptionally large prison population when there was a shortage of young men for the work force. As soon as Medvedev had made his commitment to rectifying the situation, Radchenko was hired by the Ministry of Justice to help produce a draft law - which emphasized the revival of non-custodial alternatives from the past (such as corrective work), raised the minimum values of stolen goods, decriminalized a whole series of offenses, and changed the definition of some business crimes. The latter issue had been explored by a group of jurists and economists organized by Elena Novikova, which the President converted into the Center for Legal and Economic Research connected to the Institute for Social Development (a Kremlin-sponsored think tank). This sponsorship allowed the group to expand its studies, produce a "Conception on the Modernization of Criminal Legislation in the Economic Sphere," organize hearings, and pursue lobbying activity aimed reducing the use of the criminal law in the regulation of business (Interview with Vladimir Radchenko, 2012; Kontseptsiia modernizatsii ugolovnogo zakonodatelstva ..., 2010). The ban on pretrial detention for persons charged with business crimes (April 2010) reflected the goals of this group, as did the publicizing of a case of unjustified detention of a business woman, Yana Yakovleva. 
The original draft law produced by the Ministry of Justice was reviewed and debated in summer 2010 by an interagency working group at the presidential administration with representatives of relevant agencies. Opposition to parts of the draft law led to the division of the planned changes into two separate pieces of legislation. The first one (adopted in March 2011) featured the removal of the lower limits of length of imprisonment for many common charges, and the second one (December 2011) enhanced the repertoire of non-custodial sanctions and banned the use of imprisonment for first-time offenders convicted of non-serious crimes, whose definition was also expanded so that light bodily blows (poboi), the main replacement for hooliganism, was now included. The second law also decriminalized offenses like slander and eliminated responsibility for importing legal goods into the country without payment of customs duties. But it did not respond to most of the proposals relating to business crimes; it merely provided a mechanism whereby a convicted entrepreneur could pay a large fine (four times the estimated loss) in place of a term in prison.

In short, the Medvedev humanization initiative produced a package of changes that resembled those from 2003 in introducing modest decriminalization and facilitating the avoidance by judges of imprisonment and confinement for long terms whenever the offense was not serious or the offender was nonviolent. An underlying theme was increasing judicial discretion, so that the practical meaning of the changes would depend upon how judges used their new freedom of choice.

Although the committees of the Duma and individual deputies discussed many of the issues addressed in these laws (and others that were sidelined), the main center of decision remained in the presidential administration, where the contents of the 2011 laws were discussed in a working group and further elaborated. I do not know about scholarly involvement in these later stages. It may well be that the involvement of scholars (from Radchenko, the retired judge, to the group of jurists and economists working to reduce prosecutions of businesspeople) was confined to the early stages of the process - that is, in agenda-setting rather than decision-making.

The focus on major packages of changes in the Criminal Code did not stem the flow of individual initiatives, some tending in a different direction. Even while the Medvedev humanization initiative was unfolding, other unrelated amendments to the Criminal Code were added, including one adding harsh punishments for paedophilia, changes to drug provisions, and changes relating to information technology.

Vladimir Putin's return to the presidency has led to a series of initiatives in criminal policy that come directly from the President or his staff and whose processing resembles the old pattern of changes occurring outside of codification. Prominent examples included the sudden revival of the crime of slander (barely a year after its removal from the Criminal Code) and the extension of the meaning of treason (izmena rodine) to include ordinary political activities. Probably with official support, the Orthodox church introduced a bill that makes it crime to offend the sensibilities of religious believers (a reaction to the Pussy Riot case). Various other initiatives included revised provisions on fraud (including extra liability for officials), a uniform system of compensating victims of a crime, requiring businessmen to compensate losses of their competitors before becoming 
eligible for early release, and a set of proposals for dealing with corporate raiding. So many changes in the criminal code were under discussion that one journalist wrote of the "destruction of the legislative field," and the editors of another newspaper called for a suspension of changes in the law (Golik, 2012; Ot Redaktsii: Ugolovnoe Zakonodatelstvo, 2012).

\section{Studying criminal policy-making in Russia}

Our review of criminal policy-making in Russia over seven decades confirmed that the normative ideal, cherished by some legal scholars in Russia, of a legal development shaped by their concerns about the logic and consistency of the law, has never matched the empirical reality. At best, there have been short periods of time, mainly during codification exercises, when reality approached the ideal. Even in those times, however, a broader range of factors shaped choices about the content of the law, including political ones. While from a short-term perspective, the Law of 8 December 2003 so criticized by Professor Kuznetsova may have represented a break from the dominance of legal scholars over criminal policy development of the most recent seven years, the making of that law seems normal from a longer perspective. Scholars may have expected that, after the end of communist rule, they would have a permanent role in keeping criminal law rational, consistent and effective, and unresponsive to special interests. If so, this expectation has proven to be far from realistic. As we have seen, democracies are no less vulnerable than other governments to ad hoc and impulsive uses of the criminal law.

Like their counterparts elsewhere, criminal law scholars in Russia need to uncover and accept the way that criminal policy is made, so that they can appreciate how they can best contribute to it. Scholars who refuse to recognize and explore the politics of criminal law will hold no sway against counterproductive political forces; instead they may well marginalize themselves.

I will start by summarizing what we know about criminal policy-making in the USSR and post-Soviet Russia, and then consider what we would like to know in the light of the concepts and approaches used in studies of criminal policymaking in the West.

Until 1998 the Soviet Union and post-Soviet Russia had experienced a consistent pattern of criminal policy-making - one marked by an alternation of periods of codification (efforts to address the criminal law as a whole), in which scholars played a direct, though not necessarily determinative role, and a flow of individual changes in the law usually initiated by the political leaders or high law-enforcement officials, where the involvement of scholars was infrequent and episodic. Apart from the first half of the Brezhnev period, the role of social research was also limited. To a considerable degree this represented the pattern found in countries of Western Europe.

During the years of perestroika and post-Soviet turmoil, from 1988 to the adoption of the 1996 Criminal Code, the frequency and scope of individual changes in the criminal law increased dramatically. It is possible that some of these initiatives were connected to the electoral needs of deputies from single-member districts, aware of the public insecurity produced by the crime scare of 1989 . Expectations of drafters notwithstanding, the new Code did not stem the tide, 
as deputies representing special interests as well as law enforcement kept coming forward with proposals, some of which were blocked by a group of scholars assisting the Duma committee that handled criminal law. This situation was novel in two ways: the presence of initiatives from below that had not been cleared by the authorities (i.e., the presidential administration) and the involvement of scholars with proposed changes outside of the writing of codes. As we saw, both the Federation Council and the President seized the initiative and revived a holistic approach to reform, in which the particular expert council at the Duma seems to have lost its voice. But the use of a presidential working group that represented the interested agencies was a reasonable approach, even if scholarly representation turned out to be indirect. It reproduced for criminal law the mechanism used for the judicial reform and the reform of the federal system being pursued at the same time (in contrast to the handling of the Criminal Procedure Code, where the deputy in charge was herself a scholar).

Some of the core ideas reflected in the Medvedev program for the criminal law came from legal experts who played a role in setting the agenda and suggesting relevant details, but the actual elaboration of the laws came once again through working groups representing the interested agencies. At the same time, from 2004 to 2012, the flow of individual initiatives did not cease. While some were processed, even filtered out, by the Duma committee, it appears that none was actually adopted without the agreement of the presidential administration (and, if money was involved, the government).

This summary portrait of criminal policy-making in Russia provides insights, but it lacks crucial details that might support or qualify its arguments and introduce nuances. One set of questions concerns the role and impact of deputies to the Duma. Which deputies initiated changes in the criminal law, and on whose behalf? To what extent were they personally committed to reforms? Were they in any way appealing to their own constituencies? (Arguably, the end of singlemember districts with the election of 2007 would have made such appeals pointless.) How often did deputies initiate changes in the criminal law on behalf of narrow interests, including business firms, or police seeking new tools for extracting rents from business firms? There is also the role played by chairs of key Duma committees, including Pavel Krashenennikov, and his relationship to figures in the presidential administration. Moreover, some of the proposals to change the criminal law of Russia in the new millennium came from legislative assemblies of the regions and republics, although it seems that these were often discarded before or during reviews by Duma committees.

A second group of questions concerns the presidential administration and the role that it played as a filter for proposals as well as an organizer of the drafting process. Was this activity concentrated in the State Legal Administration, and to what extent did top figures in the presidency supervise it? These are matters that require more research, including access to working documents and interviews with relevant players.

Then there are the concerns of this inquiry about the role of scholars and of evidence from research on law enforcement or judicial practice. In investigating these questions, but also the first two sets, it would be useful to keep in 
mind the distinction between agenda-setting and decision-making and to adopt a comparative perspective. First of all, in the West the involvement of experts in decision-making about criminal policy, with the exception of codification in Europe, has been consistently modest, not only with the recent onset of penal populism in some countries, but also before that and also in countries that have not experienced that phenomenon. At the same time, it is clear that criminal law scholars and criminologists alike often helped to shape the agenda for reform. They played an important part in the process of social learning that made new approaches possible. It would be worthwhile exploring and explaining analogous processes in Russia.

A fourth focus of interest is the symbolic role of law and the scope for penal populism in Russia and other countries. Arguably, symbolic politics has mattered in Russia, and explains why the government has hesitated to actually eliminate capital punishment from the criminal code (it is permanently suspended by a decision of the Constitutional Court). But direct appeals to voters to ensure support are likely to matter more in a political environment where there is competition for power between political parties and/or contestations in single-member districts where particular candidates can gain from crime-based appeals. After the election of 2003, subsequent elections to the Russian State Duma were based entirely on proportional representation with a single national constituency.

Finally, there is the urgent problem of the instability of the criminal law in Russia and what it signifies. Addressing this problem should begin with the facts, specifically, whether or to what extent the rate and depth of change since 2000 has actually been greater than it was in past periods of Russian history and than one finds in other countries in the same period. By my counts, criminal law in Russia became especially unstable in the late 1980s, when frequent changes in the law become commonplace, and the numbers of changes in the new millennium, while perhaps higher, represent a direct continuation of that trend. As we saw, in the early 1990s there were some fifty changes a year in the criminal code, and after a few years' interruption, this rate returned to the Russia of Putin and Medvedev. A recent study of changes in the criminal codes of ten post-communist countries for 1997 to 2002 found that Russia had the most changes in the period (Primakov, et al., 2010). There is evidence of frequent changes in the criminal law of other post-communist countries (Hungary) and occasional similar complaints in Western countries as well. Thus, in England and Wales, according to a muchcited newspaper article, between 1997 and 2006 some three thousand new crimes were created, and of these nearly two-thirds were done in regulations rather than through legislation (Nagy, 2007; Nigel, 2006). Only a comparative approach will elucidate what is normal. ${ }^{11}$

To understand what has happened to the criminal law in Russia calls for studies of the politics of criminal policy-making, as opposed to the narrower prism of the writing of legislation. Only in this way can the interplay of interests and the dynamics of competing views and priorities be revealed. Even when legal scholars play a significant role, one should not expect anything resembling a rational process, although more attention might be paid to the way changes in one part of the law affect other parts. 


\section{REFERENCES}

1. Barker, V. (2009). The Politics of Imprisonment: How the Democratic Process Shapes the Way America Punishes Offenders. New York: Oxford University Press.

2. Baumgartner, F., et al. (2006). Comparative Studies of Policy Agendas. Journal of European Public Policy, vol. 13, n. 7, pp. 959-74.

3. Berman, H.J. (1963). Justice in the USSR. Cambridge: Harvard University Press.

4. Boiko, A.I., Golik, V., Eliseev, A., Inogamova-Khegi, L.V., Komissarov, V.S., Koniakhin, V.P., Korobeev, A.I., Lopashenko, N.V. \& Ikushin, V.A. (2010). Oshibki v Ugolovnom kodekse. Postoiannye izmeneniia v UK napolnili ego protivorechiiami [Errors in the Criminal Code. Permanent amendments of the Criminal Code filled it with contradictions]. Rossiiskaia Gazeta, 6 October.

5. Bottoms, A.E. (1995). The Philosophy and Politics of Punishment and Sentencing. (In: The Politics of Sentencing Reform. Edited by C. Clarkson \& R. Moran). Oxford: Clarendon Press.

6. Brown, D. (2009). History's Challenge to Criminal Law Theory. Criminal Law and Philosophy, n. 3, pp. 271-87.

7. Butler, W. \& Henderson, J. (eds.) (1998). Russian Legal Texts: The Foundations of a Rule-of-Law State and a Market Economy. London: Simmonds and Hill.

8. Chernov, D. (2003). Karat' stanut miagche [Punishment will become commutative]. Vremia MN, 12 March, n. 36.

9. Criminology and Public Policy: The Vital Role of Empirical Research. In: Ideology, Crime and Criminal Justice: A Symposium in honour of Sir Leon Radzinowicz. Cullompton: Willan, 2002.

10. DiChiara, A. \& Galliher, J.I. (1994). Dissonance and Contradictions in the Origins of Marihuana Decriminalization, Law and Society Review, n. 28, pp. 41-77.

11. Downes, D. \& Morgan, R. (2007). No Turning Back: The Politics of Law and Order into the Millennium. (In: The Oxford Handbook of Criminology. Edited by Mike Maguire et al.). Oxford: Oxford University Press, pp. 201-40.

12. Downes, D. \& Swaaningen, R.van (2007). The Road to Dystopia? Changes in the Penal Climate of the Netherlands. (In: Crime and Justice in the Netherlands. Edited by Michael Tonry and Catrien Bijleveld). Chicago: University of Chicago Press.

13. Dror, Y. (1978). Public Policy-Making Reexamined. San Francisco: Chandler.

14. Eser, A. (1996). Major Stages of Criminal Law Reform in Germany. Israel Law Review, n. 30, pp. 28-35.

15. Feofanov, Yu. (1989). Vozvrashchenie k istokam (Suzhdeniia o vlasti i prave) [Returning to the sources. Judgements on power and law]. Znamia, n. 2, pp. 138-57. 
16. Gavrilov, B.Ya. (2008). Sovremennaia ugolovnaia politika Rossii: tsifry i fakty [Contemporary Criminal Policy of Russia: facts and figures]. Moscow: Prospekt.

17. Golik, Yu. (2012). "U suda net osnovanii...” Destruktsiia zakonodatelnogo polia stanovitsia vse bolee ochevidnoi [The court has no reason for ... «Destruction of the legislative field is becoming more evident]. Nezavisimaia gazeta, 4 September.

18. Gorgone, J. (1976). Soviet Jurists in the Legislative Arena: The Reform of Criminal Procedure. Soviet Union, vol. 3, n. 1, pp. 1-35.

19. Gromov, S. (2003). Negumannaia gumannost' [Inhumane Humanity]. Literaturnaia Gazeta, 9 September.

20. Gusfield, J. (1963). Symbolic Crusade: Status Politics and the American Temperance Movement. Second edition. Urbana: University of Illinois press.

21. Hood R. (1974). Criminology and Penal Change: A Case Study of the Nature and Impact of Some Recent Advice to Governments (In: Crime, Criminology and Public Policy. Edited by Roger Hood). London: Heinemann, pp. 395-418.

22. Hood, R. (1987). Some Reflections on the Role of Criminology in Public Policy. Criminal Law Review, pp.: 527-538.

23. Hood, R., \& Hoyle, C. (2009). Abolishing the death penalty worldwide: The impact of a new dynamic. Crime and Justice, n. 38, 1-63.

24. Hughes, C.E. \& Stevens, A. (2010). What Can We Learn from the Portuguese Decriminalization of Illicit Drugs? British Journal of Criminology, n. 50, pp. 999-1022.

25. Hughes, C.E. (2006). Overcoming Obstacles to Reform? Making and Shaping Drug Policy in Contemporary Portugal and Australia. Unpublished PhD thesis, Department of Criminology, University of Melbourne.

26. Interview with Vladimir Radchenko, 28 May, 2012.

27. Ismaili, K. (2006). Contextualizing the Criminal Justice Policy-making Process. Criminal Justice Policy Review, vol.17, n. 3, pp. 255-69.

28. Jones, B.D. \& Baumgartner, F.R. (2005). The Politics of Attention: How Government Prioritizes problems. Chicago: University of Chicago Press.

29. Kashepov, V.P. (2004). Kontseptsiia razvitiia ugolovnogo zakonodatelstva [The Concept of Criminal Legislation Development]. Moscow: Gorodets.

30. Kashepov, V.P. (2010). Kontseptsiia razvitiia ugolovnogo zakonodatelstva [The Concept of Criminal Legislation Development]. In: Kontseptsii razvitiia rossiiskogo zakonodatelstva. Ed. by T.Ya. Khabrieva \& Yu.A.Tikhomirov. Moscow: Eksmo, pp. 271-98.

31. Kingdom, J.C. (1995). Agendas, Alternatives, and Public Policies. $2^{\text {nd }}$ edition. New York: Harper Collins.

32. Klepitsky, I.A. (2012). Forma i tsel v ugolovnom prave [Form and Purpose in Criminal Law]. Gosudarstvo i pravo, n. 1, pp. 45-56. 
33. Komarovsky, M. (ed.) (1975). Sociology and Public Policy: The Case of Presidential Commissions. New York: Elsevier.

34. Kondratieva, M. (2003). Sazhat' budut gumannee [Imprisoning Will Be More Humane]. Gazeta, April, n. 55.

35. Krehl, C. (2003). Reforms of the German Criminal Code-Stocktaking and Perspectives-Also from a Constitutional Point of View. German Law Journal, vol. 4, n. 5, pp. $421-31$.

36. Kudriavtsev, V.N. \& Kelina, S.G. (eds.) (1987). Ugolovnyi zakon. Opyt teoreticheskogo modelirovaniia [Criminal Law. Experience of Theoretical Modeling]. Moscow: Nauka.

37. Kuznetsova N.F. (2004). Kak idei liberalizma voplotilis v reforme UK RF [How the Ideas of Liberalism Were Embodied in the Reform of the RF Criminal Code]. Chernye Dyry v Rossiiiskom Zakonodatelstve, 24 September.

38. La Pierre, B. (2012). Hooligans in Khrushchev's Russia: Defining, Policing, and Producing Deviance during the Thaw. Madison: University of Wisconsin Press.

39. Lacey, N. (2008). The Prisoners' Dilemma: Political Economy and Punishment in Contemporary Democracies. Cambridge: Cambridge University Press.

40. Lacey, N. (2012). Political Systems and Criminal Justice: the Prisoners' Dilemma after the Coalition. Current Legal Problems, pp. 1-37.

41. Loader, I. (2006). Fall of the "Platonic Guardians": Liberalism, Criminology and Political Responses in England and Wales. British Journal of Criminology, n. 46, pp. 561-586.

42. Lopashenko, N.A. (2009). Ugolovnaia politika [Criminal Policy]. Moscow: Wolters Kluwer.

43. Lord Windlesham (1996). Responses to Crime. Volume 3, Legislating with the Tide. Oxford: Clarendon Press.

44. Lord Windlesham (1998). Politics, Punishment and Populism, New York: Oxford University Press.

45. Luneev, V.V. (2011). O nauchnoi baze rossiiskogo zakonotvorchestva [On the Scientific Basis of Russian Legislation]. Posted on his blog. Available: http://crimpravo.ru/ blog/1008.html (accessed: 15 May, 2015).

46. Making Crime Pay: Law and Order in Contemporary American Politics. New York: Oxford University Press, 1997.

47. Marion, N. \& Oliver, W. (2012). The Public Policy of Crime and Criminal Justice. Second edition. Boston et al.: Prentice Hall.

48. McCain, M. (1982). Soviet Lawyers in the Reform Debate: Cohesion and Efficacy. Soviet Studies, n. 34, pp. 3-22. 
49. Merryman, J. (2007). The Civil Law Tradition. Third Edition. Stanford: Stanford University Press.

50. Miller, W. (1973). Ideology and Criminal Justice Policy. Journal of Criminal Law and Criminology, n. 64 (June), pp. 141-62.

51. Nagy, F. (2007). Transformation of Substantive Penal Law since the Political Transformation in Hungary (In: Transformation in Hungarian Law (1989-2006). Edited by Lamm, V.). Budapest: Akademia Kiado, pp. 275-208.

52. Naumov, A.V. (1997). The New Russian Criminal Code as a Reflection of Ongoing Reforms. Criminal Law Forum, vol. 8, n. 2, pp. 191-230.

53. Naumov, A.V. (2012). Prichiny nestabilnosti ugolovnogo zakonodatelstva (v svete otechestvennykh pravotvorcheskikh traditsii) [Reasons for the Instability of Criminal Legislation (In the Light of Domestic Law-Making Traditions)]. Ugolovnoe pravo: strategiia razvitiia $v$ XXI veke: Materialy IX Mezhdunrodnoi nauchno-prakticheskoi konferentsii 26-27 ianvaria 2012 g. Moscow: MGIuA, pp. 10-13.

54. Newburn, T., 'Tough on Crime': Penal Policy in England and Wales. (In: Crime, punishment and politics in comparative perspective. Crime and justice: a review of research. Vol. 36. Edited by M. Tonry). Chicago: University of Chicago Press, pp. 425-470.

55. Nigel, M. (2006). Blair's Frenzied Law-Making. The Independent, 16 August.

56. Oberwittler, D. \& Hofer, S. (2005). Crime and Justice in Germany: An Analysis of Recent Trends and Research. European Journal of Criminology, vol. 2, n. 4, pp. 465-508.

57. Ot redaktsii: Ugolovnoe zakonodatelstvo [From the Editors: Criminal Legislation]. Vedomosti, 26 September 2012.

58. Ozerova, M. \& Shipitsyna, N. (2003). Ùgolovnaia revolyutsiia [Criminal Revolution]. Moskovskii Komsomolets, 8 April.

59. Pakes, F. (2006). The Ebb and Flow of Criminal Justice in the Netherlands. International Journal of the Sociology of Law, n. 34, pp. 141-56.

60. Pomorski, S. (1998). Reflections on the First Criminal Cod of Post-Communist Russia. American Journal of Comparative Law, vol. 46, n. 2, pp. 375-93.

61. Pratt, J. (2007). Penal Populism. London: Routledge.

62. Primakov, D.Ya., et al. (2010). Zakonodatelnaia aktivnost, stabilnost zakonodatelstva $i$ kachestvo pravovoi sredy: sravnitelnyi analiz postsotsialisticheskikh stran. Analiticheskaia zapiska [Legislative Activity, Stability of Legislation and the Quality of the Legal Environment: a Comparative Analysis of the Post-Socialist Countries. Analytical Note]. St. Petersburg: Institute Problem Pravoprimeneniia.

63. Radchenko, V., Novikova, E. \& Fedotov, A. (eds.) (2010). Kontseptsiia modernizatsii ugolovnogo zakonodatelstva $v$ ekonomicheskoi sfere [The Concept of Modernization of Criminal Legislation in the Economic Sphere]. Moscow: Liberalnaia Missiia. 
64. Roberts, J., et al. (2003). Penal Populism and Public Opinion: Lessons from Five Countries. New York: Oxford University Press.

65. Rock, P. (1995). The Opening Stages of Criminal Justice Policy making. British Journal of Criminology, n. 35, pp.1-16.

66. Rothman, D. (1980). Conscience and Convenience. Boston: Little Brown, rev. ed., 2002.

67. Rothman, D. (1971). The Discovery of the Asylum. Boston: Little Brown, rev. ed, 1990.

68. Rubtsova, E. (2003). Sto i odna popravki k UK [One Hundred and One Amendments to the Criminal Code]. Russkii Kurier, 11 November.

69. Rutherford, A. (1996). Transforming Criminal Policy. Winchester: Waterside Press.

70. Schrad, M. (2010). The Political Power of Bad Ideas: Networks, Institutions, and the Global Prohibition Wave. New York: Oxford University Press.

71. Sith, K. \& Cabranes, J. (1998). Fear of Sentencing: Sentencing Guidelines in the Federal Courts. Chicago: University of Chicago Press.

72. Solomon, P. H., Jr. (2011). Criminalisation, Decriminalisation and Post-Communist Transition: the Case of the Russian Federation. (In: Building Justice in Post-Transition Europe? Processes of Criminalisation within Central and Eastern European Societies. Edited by Kay Goodall, et al.). London: Routledge, pp. 95-114.

73. Solomon, P. H., Jr. (1978). Soviet Criminologists and Criminal Policy: Specialists in Policy-Making. New York: Columbia University Press.

74. Solomon, P. H., Jr. (1981). The Policy Process in Canadian Criminal Justice: A Perspective and Research Agenda. Canadian Journal of Criminology, vol. 23, n. 1, pp. 5-25.

75. Solomon, P. H., Jr. (1998 and 2008). Soviet Criminal Justice under Stalin. Cambridge: Cambridge University Press, pp. 406-408.

76. Solomon, P. H., Jr. (2013). Courts, Law and Policing under Medvedev: Many Reforms, Modest Change, New Voices. Edited by Larry Black and Michael Johns. London: Routledge.

77. Solomon, P. H., Jr. (1992). Reforming Criminal Law under Gorbachev: Crime, Punishment, and the Rights of the Accused. (In: Toward the "Rule of Law" in Russia? Political and Legal Reform in the Transition Period. Edited by Donald D. Barry). Armonk, NY: M.E. Sharpe, pp. 235-56.

78. Stolz, B. (1985). Congress and Criminal Justice Policy-making: The Impact of Interest Groups and Symbolic Politics. Journal of Criminal Justice, n. 13, pp. 307-19.

79. Stolz, B. (2002). Criminal Justice Policy-making: Federal Roles and Processes. Westport, CT: Praeger.

80. Sukhov, I. (2003). UK v myagkoi manere [CC in soft manner]. Vremia Novostei, 12 March. 
81. Svetova, Z. (2003). Uzakonennaia gumannost [Legalized Humanity]. Russkii Kurier, 19 November.

82. Tonry, M. (2004). Why Aren't German Penal Policies Harsher and Imprisonment Rates Higher? German Law Journal, vol. 5, n. 10, pp. 1187-1206.

83. Tonry, M. (2007). Determinants of Penal Policies (In: Crime, Punishment and Politics in Comparative Perspective. Edited by M. Tonry). Chicago: University of Chicago Press, pp. 1-48.

84. Ugolovnyi Kodeks Rossiiskoi Federatsii: Ofitsialnyi Tekst [The Criminal Code of the Russian Federation: the Official Text]. Moscow, 1996.

85. Zedner, L. \& Ashworth, A. (eds.) The Criminological Foundations of Penal Policy; Essays in Honour of Robert Hood. Oxford: Oxford University Press, 2003.

86. Zhalinsky, A.E. (2010). Ugolovnaia politologiia: stanovlenie i razvitie [Criminal Politology: formation and development]. Pravo i politika, n. 5, pp. 826-34.

87. Zhalinsky, A.E. (2010). Ugolovnaia politologiia i ugolovnaia politika: neobkhodimost novogo podkhoda [Criminal Politology and Criminal Policy: the Need for a New Approach] (In: Ugolovnaia politika i pravo v epokhu peremen: Materialy mezhdunarodnoi naucho-prakticheskoi konferentsii posviashchennoi pamiati professora P.S. Dagelia. Edited by A.N. Korobeev). Vladivostok: Dalnevostochnyi universitet, pp. $8-26$.

88. Zimring, F. \& Haskins G. (1986). Capital Punishment and the American Agenda. Cambridge: Cambridge University Press.

89. Zimring, F., Hawkins, G. \& Kamin, S. (2001). Punishment and Democracy: Three Strikes and You're Out in California. New York: Oxford University Press.

The senior author is grateful to Ben Noble for his research assistance in Moscow and thoughtful comments. He also thanks Leon Kosals for comments and Milosz Zak for assistance in Toronto. The writing of this report was supported by the "Rule of Law and Economic Development" project at McGill University Faculty of Law. Mr. Noble's research was made possible by a Leverhulme Trust Study Abroad Studentship. 


\section{NOTES}

1 By 2012 a sizeable share of criminal law scholars believed that criminal law in Russia was experiencing a crisis, for which a new Code or at least a new edition of the current code was the answer. See the survey of scholars conducted by the Saratov Center for the Study of Organized Crime and Corruption at "Otsenka uchenymi rossiiskogo UK i ugolovnoi politiki," http://info-pravo.com/blob/otsenka_uchenymi_rossijkogo_uk_i_ugolovnoj_politiki/2012...”

2 For explication of the rational model of policy-making see Dror (1978), as well as most textbooks in public policy. A criminologist who has eloquently articulated the ideal way that criminal policy should be made is Roger Hood. See his "Some Reflections on the Role of Criminology in Public Policy" (1987) and Criminology and Public Policy: The Vital Role of Empirical Research" (2002). See also Lucia Zedner and Andrew Ashworth (2003), introduction and passim.

3 Perhaps, some legal scholars believed that by investigating the political bases of criminal policy, they would be giving legitimacy to tendencies of which they disapproved.

$4 \quad$ See, for example, "Public Criminologies," a symposium with seven articles, in Criminology and Public Policy, 9: 3 (2010), pp. 721-805, especially the lead article Uggen, Ch. \& Inderbitzen, M. "Public Criminologies."

5 In Common law countries many criminal law scholars bemoaned the failure of legislatures to pay heed to criminal law theory and its purveyors. See for example Darryl Brown, (2009).

6 See: Solomon, Jr.(1978, Ch. 2); Solomon, Jr. (1996), pp., 406-408. For discussions of the draft criminal codes of the late 1940s, see GARF, f.9492, op.1, d.1962 and 1963; f.9492sch, op.2s, d.45 and d.49; f.7523sch, op.65s, d.243.

7 "Ugolovnyi Kodeks RSFSR ot 27 oktiabria 1960 g., izmeneniia i dopolneniia k kodeksu," Ugolovnyi kodeks RSFSR i Ugolovno-protsessualnyi kodeks RSFSR. Moscow: BEK, 1995, 19-50. Anatoly Naumov has done similar counts for earlier periods in Russia and Soviet history, demonstrating the relative stability of the criminal law that characterized those eras (2012, pp. 10-13).

$8 \quad$ Poiasnitelnaia zapiska k proektu federalnogo zakona "O vnesenii izmenenii i dopolonenii v Ugolovnyi Kodeks Rossiiskoi Federatsii” (n.d., 2003).

9 Data from the website of the Judicial Department (www.cdep.ru ), as compiled by Todd Foglesong.

10 This section is based upon Peter H. Solomon, Jr. (2011) and Peter H. Solomon, Jr. (2013). References to primary sources are provided in these places.

11 Benjamin Noble is collecting data on patterns of change in criminal codes in a variety of countries. 